\title{
KEANEKARAGAMAN BURUNG DI KAMPUS UIN RADEN INTAN LAMPUNG
}

\author{
Amanda Apriliano ${ }^{1}$, Chairul Anwar ${ }^{2}$, Suci Wulan Pawhestri ${ }^{3}$, Rina Budi Satiyarti ${ }^{4}$ \\ 1,2,3,4 UIN Raden Intan Lampung, Jl. Letkol H. Endro Suratmin Sukarame Bandar Lampung \\ amanda.apriliano@gmail.com
}

Diterima : 12 November 2018. Disetujui: 29 November 2018. Dipublikasikan: 29 Desember 2018

\begin{abstract}
Biodiversity of Indonesia is worldwide known. One of those is bird biodiversity. The native utilize birds as a pet. It is because birds have a beautiful color and voice. Therefore, Rare birds is likely to be hunted to get their aesthetic value. Raden intan Islamic ngy (UIN RIL) were a part of city forest. Trees and scrub were considered as bird habitat. The aim of this research is to identify birds in UINRIL campus, gruping the bird based on their exctinction.This research was done in five station each three times. The method is point count. All data were collected at 06.00-09.00 and 15.00-18.00 WIB. Data were analyzing using deskriptif quantitative approach. Diversity index ( $\left.H^{\prime}\right)$ for all station is 1166-2531.Diversity average at all station were(H') 2,023. This research had success write 24 species of birds from 16 famili. Three of them were under government surveillance pp no. 7 year 1999. They are cekakak sungai(Todirhamphus chloris ), madu sriganti (Nectarinia jugularis), and madu kelapa (Anthreptes malacensis).
\end{abstract}

Keywords: Bird, Biodiversity, UIN Raden Intan Lampung

\begin{abstract}
ABSTRAK
Kekayaan hayati fauna Indonesia telah dikenal oleh dunia. Salah satunya adalah terdapatnya beranekaragam burung di Indonesia. Masyarakat Indonesia memanfaatkan burung sebagai hewan peliharaan . Hal ini dikarenakan burung memiliki warna bulu dan suara yang indah. Oleh karena itu, banyak terjadi perburuan burung langka oleh manusia untuk mendapatkan nilai estetikanya. Kampus Universitas Islam Negeri Raden Intan Lampung termasuk kedalam hutan kota. Area pepohonan yang tinggi dan semak belukar pada kampus UIN RIL dapat menjadi habitat burung. Tujuan penelitian ini adalah mengidentifikasi jenis-jenis burung yang terdapat di Kampus UIN RIL dan mengetahui status burung-burung tersebut. Penelitian dilakukan di lima stasiun berbeda dengan tiga kali pengulangan. Metode yang digunakan adalah metode point count (titik hitung). Pengambilan data dilaksanakan pada pukul 06.00 -09.00 dan $15.00-18.00$ WIB. Data yang didapatkan kemudian dianalisis melalui pendekatan deskriptif kuantitatif. Indeks keanekaragaman (H') pada kelima stasiun berkisar 1.166-2.351. Rata-rata indeks keanekaragam burung pada semua stasiun adalah (H') $=2.023$. Burung yang tercatat meliputi 24 spesies dari 16 famili. Tecatat 3 spesies yang di lindungi oleh peraturan pemerintah no. 7 tahun 1999 yaitu burung cekakak sungai ( Todirhamphus chloris ), burung madu sriganti ( Nectarinia jugularis ), dan burung madu kelapa ( Anthreptes malacensis).
\end{abstract}

Kata Kunci: Burung, Keanekaragaman, UIN Raden Intan Lampung.

\section{PENDAHULUAN}

Keanekaragaman hayati yang dimiliki Indonesia sangat melimpah, meliputi flora dan fauna. Salah satunya adalah keanekaragaman fauna yang dimiliki Indonesa adalah Burung. Burung adalah kelompok hewan vertebrata yang berkembang biak secara kawin, memiliki bulu indah dengan bermacam warna, suara yang merdu, serta tingkah lakunya yang menarik (Kamal, Mahdi, \& Senja, 2013). Burung juga merupakan satwa yang dinilai 
penting pada ekosistem taman karena turut membantu penyerbukan bunga, penyebaran benih, dan mencegah kerusakan tumbuhan dari serangga (Endah \& Partasasmita, 2015).

Keberadaan burung dapat dijadikan indikator suatu lingkungan dalam mendukung kehidupan suatu organisme atau karena mempunyai hubungan timbal balik dan saling tergantung dengan lingkungannya. Burung sebagai indikator adanya perubahan lingkungan, dapat digunakan sebagai indikator dalam mengambil suatu keputusan tentang rencana strategis dalam rangka konservasi lingkungan yang lebih luas (Paramita, Kuntjoro, \& Ambarwati, 2015).

Sebanyak 9.040 jenis burung yang tercatat di dunia, 1.539 jenis diantaranya terdapat di negara Indonesia dengan 397 jenis (26\%) endemic. Dari 1.539 spesies burung yang ada di Indonesia, 104 spesies dikategorikan sebagai terancam punah secara menyeluruh, sementara 152 spesies lainnya tergolong pada kategori mendekati terancam punah (Mardiastuti, Kusrini, Mulyani, \& Soehartono, 2008).

Burung sering kali diburu untuk dimanfaatkan nilai estetikanya. Upaya konservasi burung untuk mengimbangi minat masyarakat masih sangat kurang sehingga keberadaan burung mulai terancam punah. Salah satu upaya konservasi burung adalah dengan penangkaran burung baik secara in situ maupun ex situ (Bahtiar, Susanti, \& Rahayuningsih, 2014). Konservasi in situ meliputi cagar alam, suaka marga satwa, dan taman nasional, sedangkan konsevasi ex-situ meliputi, kebun raya, dan hutan kota.

Kampus Universitas Islam Negeri Raden Intan yang berada di Jalan Letkol H Endro Suratmin kecamatan Sukarame Bandar Lampung, memiliki vegetasi yang cukup beragam di kota Bandar Lampung. Tahun 2008 pemerintah Kota Bandar Lampung menetapkan UIN Raden Intan Lampung sebagai Kawasan Hutan Kota dan daerah di sekitarnya yaitu Lapangan Golf Sukarame, SMAN 12 Bandar Lampung, dan SMPN 24 Bandar Lampung. Penetapan UIN Raden Intan Lampung yang tercantum dalam Surat Keputusan Walikota Bandar Lampung Nomor: 39/ 04/ HK/ 2008 menetapkan bahwa UIN Raden Intan Lampung sebagai pengelola pembuatan Hutan Kota dari kegiatan Gerakan Nasional Rehabilitasi dan Lahan tahun 2005.

Berdasarkan hasil penelitian terdahulu, beberapa penelitian mengidentifikasi keanekaragaman hayati menggunakan burung sebagai indikatornya meliputi beberapa daerah/kabupaten (Endah \& Partasasmita, 2015; Hidayat \& Dewi, 2017; Jumilawaty, 
Mardiastuti, Prasetyo, \& Mulyani, 2011; Kamal, 2017, 2018; Mashudi \& Marhento, 2016; Rahayuningsih, Purnomo, \& Priyono, 2010; Rusmendro, 2009; Santosa, Harianto, \& Nircahyani, 2016), taman nasional (Bahtiar et al., 2014; Kartijono, Rahayuningsih, \&Abdullah, 2010; Nurmaeti, Abidin, \& Prianto, 2018; Qiptiyah, Broto, \& Setiawan, 2013; Sawitri \& Iskandar, 2012; Winara, 2015) bahkan hutan (Hamzati \& Aunurohim, 2013; Kamal, 2016; Kamal, Agustina, \& Azhari, 2018; Kamal et al., 2013; Paramita et al., 2015; Rohiyan, Setiawan, \& Rustiati, 2014; Widodo, 2010) yang dihubungkan dengan pola perubahan habitat dan masalah lingkungan. Namun, belum terdapatpenelitian sebelumnya yang mengidentifikasi keanekaragaman hayati menggunakan burung sebagai indikatornya di kampus UIN Raden Intan Lampung. Berdasarkan latar belakang tersebut maka, penelitian ini bertujuan untuk(1)Mengetahui nilai indeks keanekaragaman burung di kampus UIN Raden Intan Lampung, (2)Mengetahui jumlah jenis burung yang terdapat di kampus UIN Raden Intan Lampung serta (3)Mengetahui burung berstatus dilindungi yang ditemukan di kampus UIN Raden Intan Lampung.

\section{METODE PENELITIAN}

Pengamatan dilakukan pada pukul 06:00-09:00 WIB dan pukul 15:00-18:00 sebanyak 3 kali pengulangan pada 5 stasiun pengamatan. Penentuan stasiun pengamatan dilakukan dengan studi pendahuluan. Penelitian pendahuluan ditujukan untuk melihat frekuensi perjumpaan berbagai jenis burung. Pengamatan dilakukan secara langsung dengan cara mencatat pada tabel pengamatan. Pencatatan meliputi waktu perjumpaan, nama spesies, dan jumlah spesies.
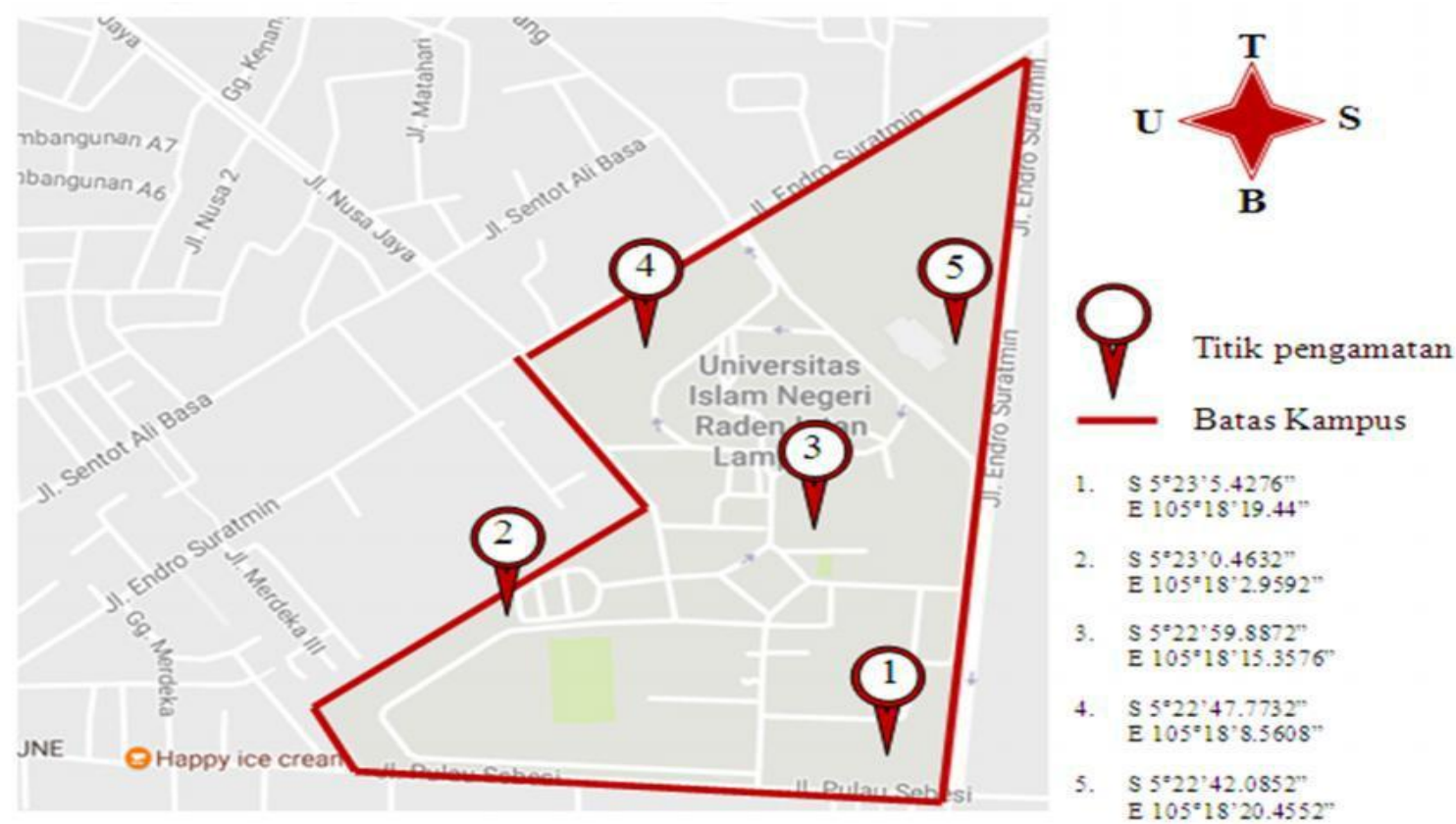


\section{Gambar 1. Peta Lokasi Pengamatan}

Metode pengamatan yang digunakan adalah metode dengan titik hitung (point count)(Endah \& Partasasmita, 2015; Hidayat \& Dewi, 2017; Kamal, 2018; Kamal et al., 2018, 2013; Kartijono et al., 2010; Rahayuningsih et al., 2010; Rusmendro, 2009; Saefullah, Mustari, \& Mardiastuti, 2015; Santosa et al., 2016). Pada metode ini pengamatan hanya tetap berdiri dalam suatu lokasi yang telah ditentukan selama periode waktu tertentu sambil mencatat serta menghitung burung(Colin, Martin, \& Stuart, 2000).

Alat-alat yang digunakan pada penelitian ini adalah Kamera DSLR Merk Canon seri 7D dengan lensa tele oom length focal 75-300 mm, GlobalPositioning System (GPS), jam tangan,alat tulis, dan buku identifikasi spesies burung yang berjudul "Seri Panduan Lapangan Burung-Burung di Sumatera, Jawa, Bali dan Kalimantan” (Endah \& Partasasmita, 2015; John, Karen, \& Bas, 2010).

Data yang didapat dianalisa menggunakan rumus Kelimpahan dan Indeks keanekaragaman Shannon-Wiener. Rumus-rumus tersebut dituliskan sebagai berikut:

1. Kelimpahan

Kelimpahan jenis:

$$
P i=\frac{\sum \text { Burung spesies } i}{\sum \text { total burung }}
$$

2. Indeks Keanekaragaman

$$
H^{\prime}=-\Sigma P i \ln (P i)
$$

Keterangan :

$H^{\prime} \quad=$ Indeks keanekaragaman Shannon-Wienner

$n i=$ Jumlah individu spesies ke-i

$\mathrm{N} \quad=$ Jumlah individu seluruh spesies

Kriteria nilai indeks keanekaragaman Shannon-Wiener $\left(H^{\prime}\right)$ adalah:

$H^{\prime}<1 \quad$ : keanekaragaman rendah

$1<H^{\prime}<3$ : keanekaragaman sedang 
$\mathrm{H}^{\prime} \geq 3 \quad$ : keanekaragaman tinggi

\section{HASIL PENELITIAN DAN PEMBAHASAN}

Berdasarkan hasil penelitian, telah tercatat ada 24 jenis burung yang terdiri dari 16 famili. Jumlah individu burung pada setiap stasiun berbeda-beda dapat dilihat pada Tabel 1.

Tabel 1. Spesies-spesies Burung dan Jumlah Individu pada Lima Stasiun Pengamatan di Kampus UIN Raden Intan Lampung

\begin{tabular}{|c|c|c|c|c|c|c|c|}
\hline \multirow{2}{*}{ No } & \multirow{2}{*}{ Nama Spesies } & \multirow{2}{*}{ Nama Ilmiah } & \multicolumn{5}{|c|}{ Jumlah Individu (Stasiun) } \\
\hline & & & 1 & 2 & 3 & 4 & 5 \\
\hline 1 & Apung Tanah & Anthus novaeseelandiae & & & & & 10 \\
\hline 2 & Bentet Kelabu & Lanius schach bentet & & 4 & & & \\
\hline 3 & Bondol Jawa & Lonchura leucogastroides & & 3 & & 1 & \\
\hline 4 & Bondol Oto Hitam & Lonchura ferruginosa & & & 2 & & 1 \\
\hline 5 & Bondol Peking & Lonchura punctulata & & 6 & 16 & 9 & 3 \\
\hline 6 & Bubut Alang-Alang & Centropus bengalensis & & 8 & & & 1 \\
\hline 7 & Burung Cabai Jawa & Dicaeum trochileum & & & 2 & 4 & \\
\hline 8 & Burung Gereja Erasia & Passer montanus & 65 & & $` 10$ & 6 & 16 \\
\hline 9 & Burung Madu Kelapa & Anthreptes malcensis & 1 & & & 1 & 1 \\
\hline 10 & Burung Madu Sriganti & Nectarinia jugularis & 5 & & 2 & 3 & 1 \\
\hline 11 & Caladi Tilik & Picoides moluccensis & 2 & & 4 & & \\
\hline 12 & Cekakak Sungai & Todhirhamphus chloris & 1 & 3 & 2 & 1 & 2 \\
\hline 13 & Cucak Kutilang & Pycnonotus aurigaster & 1 & 26 & 21 & 17 & 12 \\
\hline 14 & Gemak Loreng & Turnix suscitator & & 2 & & & 1 \\
\hline 15 & Kapasan Kemiri & Lalage nigra & 4 & & 4 & 9 & 1 \\
\hline 16 & Kareo Padi & Amaurornis phoemicurus & & 6 & & & 1 \\
\hline 17 & Kekep Babi & Artamus leucorhychus & & 16 & 2 & 1 & 2 \\
\hline 18 & Kerak Kerbau & Acridotheres javanicus & & & & & 1 \\
\hline 19 & Layang-Layang Batu & Hirundo tahitica & & & & 4 & \\
\hline 20 & Mandar Padi Sintar & Galliralus striatus & & & & & 1 \\
\hline 21 & Perkutut Jawa & Geopelia stiata & 1 & 1 & 6 & 6 & 13 \\
\hline 22 & Remetuk Laut & Gerygone sulphurea & & & & & \\
\hline 23 & Tekukur Biasa & Streptopelia chinensis & 1 & 5 & 1 & 4 & 4 \\
\hline 24 & Walet Sapi & Collocalia esculenta & 16 & 2 & 1 & 21 & \\
\hline \multicolumn{3}{|c|}{ Jumlah seluruh Individu } & 97 & 82 & 75 & 96 & 85 \\
\hline \multicolumn{3}{|c|}{ Total seluruh Individu } & \multicolumn{5}{|c|}{435} \\
\hline
\end{tabular}

Berdasarkan Tabel 1, jumlah individu terbanyak yang ditemukan yaitu burung gereja erasia (Passer montanus) pada stasiun 1, berjumlah 65 ekor. Sedangkan burung yang 
jumlahnya paling sedikit ditemukan yaitu burung kerak kerbau ( Acridotheresjavanicus ) dan burung mandar padisintar ( Galliralus striatus ), ditemukan pada stasiun 5 yang hanya tercatat sekali selama penelitian.

Berdasarkan hasil pengolahan data nilai kelimpahan (Pi), nilai kelimpahan spesies tertinggi adalah burung gereja erasia (Passer montanus) sebesar 0,670 pada stasiun 1 . Burung mandar padi sintar (Galliralus striatus) dan kerak kerbau (Acridotheresjavanicus) merupakan burung dengannilai kelimpahannya paling kecil, yaitu sebesar 0,012 pada stasiun 5.

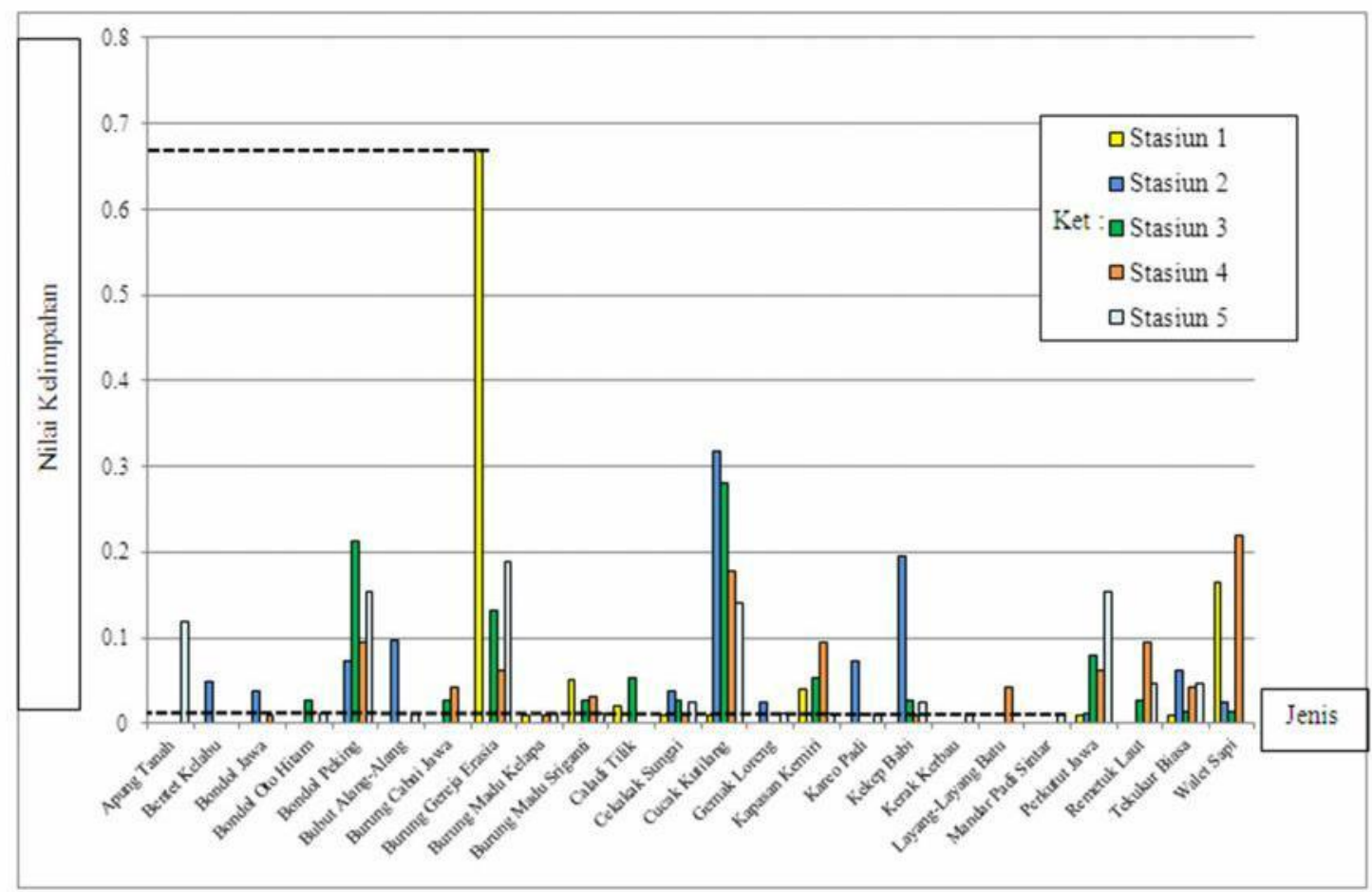

Gambar 2. Grafik Kelimpahan

Berdasarkan hasil dari pengolahan data Indeks Keanekaragaman Shannon-Wienner $\left(H^{\prime}\right)$, terdapat perbedaan pada setiap stasiun pengamatan. Indeks keanekaragaman tertinggi pada stasiun 5 dengan nilai indeks 2.351, sedangkan indeks keanekaragaman terendah pada stasiun 1 dengan nilai indeks 1.166. Rerata indeks keanekaragaman yaitu 2.023.

Tabel 2. Indeks Keanekaragaman Shannon-Wienner

\begin{tabular}{|c|c|c|c|c|c|}
\hline Indeks Keanekaragaman Shannon & \multicolumn{5}{|c|}{ Stasiun } \\
\cline { 2 - 6 } & 1 & 2 & 3 & 4 & 5 \\
\hline Wienner ( H' ) & 1.166 & 2.088 & 2.164 & 2.347 & 2.351 \\
\hline Rata-rata & \multicolumn{5}{|c|}{2.023} \\
\hline
\end{tabular}


Berdasarkan Tabel 2, dapat dilihat bahwa jumlah spesies burung yang terdapat di kampus UIN RIL yaitu 24 spesies yang berasal dari 18 famili. Hasil analisis perhitungan keanekaragaman burung di kampus UIN Raden Intan Lampung pada 5 stasiun pengamatan seluruhnya dikategorikan sedang. Rata-rata indeks keanekaragaman burung menunjukkan nilai 2.023 .

Keanekaragaman burung pada setiap stasiun berbeda-beda dikarenakan kondisi tempat yang berbeda. Stasiun 1 terletak pada kordinat $5^{\circ} 23^{\prime} 5,4276^{\prime \prime}$ LS dan $105^{\circ} 18^{\prime} 19,44^{\prime \prime}$ BT berdekatan dengan gedung perkuliahan Fakultas Ekonomi Bisnis Islam(FEBI) dan Fakultas Tarbiyah (FTK). Stasiunini adalah stasiun dengan nilai indeks keanekaragaman terendah dibandingkan dengan stasiun pengamatan lainnya. Indeks keseragaman pada stasiun 1 adalah 1,166. Keanekaragaman burung di stasiun ini diduga karena adanya aktivitas manusia, seperti kegiatan perkuliahan, dan lalu lintas kendaraan bermotor. Merujuk pada penelitian Puspita Endah, aktivitas manusia akan menjadi suatu gangguan terhadap keberadaan burung di suatu wilayah tertentu(Endah \& Partasasmita, 2015).

Selain aktivitas manusia, hal lainya yang menyebabkan rendahnya indeks keanekaragaman burung yaitu vegetasi. Stasiun ini mempunyai vegetasi yang tidak beragam, hanya didominasi oleh pohon akasia ( Acacia auriculiformis ). Suatu wilayah dengan vegetasi yang sama, akan cenderung menurunkan keanekaragaman burung pada suatu wilayah tertentu. Menurut Firdaus, Setiawan dan Rustiati dalam Apri Hidayat mengemukakan bahwa "Daya dukung variasi vegetasi merupakan salah satu faktor yang menghubungkan antara keanekaragaman spesies burung dan keseimbangan komunitas, yaitu jika keanekaragaman tinggi, maka keseimbangan komunitasnya juga tinggi” (Hidayat \& Dewi, 2017).

Stasiun 2 terletak pada kordinat $5^{\circ} 23^{\prime} 0,4632^{\prime \prime}$ LS dan $105^{\circ} 18^{\prime} 19,44^{\prime \prime} \mathrm{BT}$, memiliki kondisi yang minim aktivitas manusia. Spesies burung yang tercatat pada stasiun ini adalah sebanyak 12 spesies. Stasiun 2 merupakan stasiun dengan semak belukar yang cukup luas. Burung bubut alang-alang ( Centropusbengalensis ) merupakan burung yangmemanfaatkan vegetasi seperti ini.

Indeks keanekaragaman burung tertinggi terletak pada stasiun 5, yaitu 2,351. Stasiun 5 terletak pada $5^{\circ} 22^{\prime} 42.0852^{\prime \prime L S}$ dan $105^{\circ} 18^{\prime} 20.4552 " B T$ berdekatan dengan 
gedung serbaguna UIN. Tercatat jumlah spesies burung yang terdpat pada stasiun ini yaitu 18 spesies selama periode pengamatan. Tingginya indeks keanekaragaman stasiun ini diduga karena rendahnya aktivitas manusia dan vegetasi yang beragam.

Vegetasi pada stasiun ini meliputi pohon akasia (Acaciaauriculiformi), pohon dinamit (Hura brasiliensis), pohon jati (Tectona grandis), dan semak belukar. Terdapatsatu spesies yang jarang ditemukan dan tercatat satu kali selama periode pengamatan yaitu burung mandar padi sintar (Galliralus stiatus).

Burung mandar padi sintar (Galliralus stiatus) memilikikebiasaan menyendiri, dan jarang sekali ditemukan. Burung ini terlihat hanya pada sore hari, diantara semak belukar. Menandakan burung ini memulai aktivitasnya malam hari, karena umumnya beraktivitas pada waktu malam. Jenis ini ditemukan di kampus UIN Raden Intan Lampung, pada penelitian yang dilakukan oleh Agus Setiawan mengenai keanekaragaman burung di hutan kota Bandar lampung tidak ditemukan, hal ini dapat menandakan bahwa kampus UIN raden Intan Lampung memiliki habitat yang cocok untuk burung ini hidup.

Berdasarkan hasil penelitian didapatkan 3 spesies burung yang berstatus dilindungi pemerintah atas dasar peraturan pemerintah nomor 7 tahun 1999 tentang pengawetan jenis tumbuhan dan satwa, yaitu Cekakak sungai (Todirhamphuschloris), Burung madu sriganti (Nectarinia jugularis) dan Burung madukelapa (Anthreptes malacensis ).

Jenis burung dari famili alcediniidae yang ditemukan pada saat pengamatan adalah burung cekakak. Burung cekakak sungai ditemukan di semua stasiun pengamatan. Pemerintah menetapkan status pada burung ini sebagai burung yang dilindungi. Menurut Rizki Agung, spesies ini adalah burung yang peka terhadap perubahan lingkungan(Santosa et al., 2016). Alih fungsi lahan dan pembangunan gedung adalah faktor yang menyebabkan burung cekakak sungai sulit ditemui. Menurut data IUCN (InterntionalUnion for Conservation of Nature)populasi cekakak sungai turun dalam kurun waktu 10 tahun terakhir. Spesies ini diduga mengalami penurunan populasi karena kerusakan hutan bakau yang berlangsung dan pembangunan.

Jenis burung dari famili nectarinidae yang ditemukan di lokasi penelitian adalah burung madu sriganti ( Nectarinia jugularis) dan Burung madukelapa (Anthreptes malacensis). Burung ini termasuk kedalam burung yang dilindungi karena berperan penting dalam ekosistem yaitu penyerbukan. Burung ini spesifik memakan nektar. Menurut 
MacKinnon dalam Gammi Puspita Endah mengatakan bahwa "Burung Madu Sriganti merupakan burung-madu yang paling umum di daerah dataran rendah terbuka di seluruh Sunda Besar" (Endah \& Partasasmita, 2015).

Burung memiliki peran yang penting dalam suatu ekosistem. Peran burung didalam ekosistem sebagai komponen penyeimbang dalam ekosistem karena perannya sebagai agen penyebaran biji, penyerbukan, dan pengendalian hama. Kampus UIN Raden Intan Lampung memiliki indeks keanekaragaman yang sedang, hal ini disebabkan karena komponen penyusun ekosistem dalam wilayah kampus stabil atau timbal balik antara komponen biotik dan abiotik pada ekosistem kampus tersebut seimbang. Wilayah kampus yang yang dijadikan hutan kota pada tahun 2010 memiliki peran untuk menjadikan saranan ruang terbuka hijau sekaligus menjadikan konservasi eksitu mengingat pada Undang-Undang nomor 5 tahun 1990 tentang konservasi sumber daya alam hayati dan ekosistemnya. Hal ini didukung dengan penemuan burung-burung yang dilindungi seperti burung madu kelapa (Anthreptes malacensis), burung madu sriganti (Nectariniajugularis) dan burung cekakak sungai(Todirhamphus chloris).

\section{SIMPULAN DAN SARAN}

Berdasarkan hasil penelitian yang telah dilakukan dapat disimpulkan bahwa (1)Indeks keanekaragaman burung di kampus UIN Raden Intan Lampung dikatagorikan sedang $\left(H^{\prime}=2.023\right)$ (2)Terdapat 24 jenis burung dari 16 famili burung yang teramati di Kampus UIN Raden Intan Lampung (3)Burung cekakak sungai (Todirhamphus chloris), burung madu sriganti (Nectariniajugularis), dan burung madu kelapa(Anthreptes malacensis) merupakan spesies yang berstatus dilindungi yang tertera pada lampiran peraturan pemerintah no. 7 tahun 1999 tentang PengawetanJenis Tumbuhan dan Satwa.

Untuk meningkatkan keanekaragaman jenis burung di kampus UIN Raden Intan Lampung, pihak kampus serta pemerintah Kota Bandar Lampung perlu meningkatkan keanekaragaman jenis pepohonan serta perlu dijaga kelestarian kampus UIN Raden Intan Lampung agar nilai keanekaragaman burung tidak mengalami penurunan.

\section{DAFTAR PUSTAKA}

Bahtiar, D. H., Susanti, R., \& Rahayuningsih, M. (2014). Keanekaragaman Jenis Ektoparasit Burung Paruh Bengkok Famili Psittacidae di Taman Margasatwa 
Semarang. Unnes Journal Of Life Science, 3(2), 139-147.

Colin, B., Martin, J., \& Stuart, M. (2000). Teknik-Teknik Ekpedisi Lapangan Survei Burung. Bogor: Bird Life Internasional-Indonesia.

Endah, G. P., \& Partasasmita, R. (2015). Keanekaan Jenis Burung di Taman Kota Bandung, Jawa Barat. In Pros Sem Nas Masy Biodiv Indon (Vol. 1, pp. 1289-1294).

Hamzati, N. S., \& Aunurohim. (2013). Keanekaragaman Burung di Beberapa Tipe Habitat di Bentang Alam Mbeliling Bagian Barat, Flores. Jurnal Sains dan Seni Pomits, 2(2), $121-126$.

Hidayat, A., \& Dewi, B. S. (2017). Analisis Keanekaragaman Jenis Burung Air di Divisi I dan Divisi II PT. Gunung Madu Plantations Kabupaten Lampung Tengah Provinsi Lampung. Jurnal Sylva Lestari, 5(3), 30-38.

John, M., Karen, P., \& Bas, V. B. (2010). Burung-Burung di Sumatera, Jawa, Bali dan Kalimantan. Bogor: Lipi.

Jumilawaty, E., Mardiastuti, A., Prasetyo, L. B., \& Mulyani, Y. A. (2011). Keanekaragaman Burung Air di Bagan Percut, Deli Serdang Sumatera Utara. Media Konservasi, 16(3), 108-113.

Kamal, S. (2016). Keanekaragaman Jenis Burung Predator Serangga di Kawasan Hutan Sekunder Rinon Pulo Aceh. In Prosiding Seminar Nasional Biotik 2016 (pp. 173179).

Kamal, S. (2017). Keanekaragaman Jenis Burung di Kawasan Pesisir Deudap Pulo Aceh Kabupaten Aceh Besar. In Prosiding Seminar Nasional Biotik 2017 (pp. 252-259).

Kamal, S. (2018). Keanekaragaman Jenis Burung di Kawasan Kegiatan Pembangunan PLTM Krueng Isep PT Senagan Energi Kabupaten Nagan Raya. In Prosiding Seminar Nasional Biotik 2018 (pp. 285-292).

Kamal, S., Agustina, E., \& Azhari. (2018). Keanekaragaman Spesies Burung pada Beberapa Tipe Habitat di Kawasan Taman Hutan Raya Pocut Meurah Intan Provinsi Aceh. In Prosiding Seminar Nasional Pendidikan Biologi (pp. 751-757).

Kamal, S., Mahdi, N., \& Senja, N. (2013). Keanekaragaman Jenis Burung pada Perkebunan Kopi di Kecamatan Bener Kelipah Kabupaten Bener Meriah Provinsi Aceh. Jurnal Biotik, 1(2), 73-79.

Kartijono, N. E., Rahayuningsih, M., \& Abdullah, M. (2010). Keanekaragaman Jenis Vegetasi dan Profi L Habitat Burung di Hutan Mangrove Pulau Nyamuk Taman Nasional Karimunjawa. Biosaintifi Ka, 2(1), 27-39.

Mardiastuti, A., Kusrini, M., Mulyani, Y. A., \& Soehartono, T. (2008). Arahan Strategis Konservasi Spesies Nasional 2008-2018. Jakarta: Departemen Kehutanan Ri.

Mashudi, A., \& Marhento, G. (2016). Identifikasi Keanekaragaman Jenis Burung dan 
Kearifan Tradisional Masyarakat dalam Upaya Konservasi di Pulau Rambut Kepulauan Seribu. Jurnal Formatif, 6(2), 119-124.

Nurmaeti, C., Abidin, Z., \& Prianto, A. (2018). Keanekaragaman Burung pada Zona Penyangga Taman Nasional Gunung Ciremai. Quagga, 10(2), 54-59.

Paramita, E. C., Kuntjoro, S., \& Ambarwati, R. (2015). Keanekaragaman dan Kelimpahan Jenis Burung di Kawasan Mangrove Center Tuban. Lenterabio, 4(3), 161-167.

Qiptiyah, M., Broto, B. W., \& Setiawan, H. (2013). Keragaman Jenis Burung pada Kawasan Mangrove di Taman Nasional Rawa Aopawatumohai. Jurnal Penelitian Kehutanan Wallacea, 2(1), 41-50.

Rahayuningsih, M., Purnomo, F. A., \& Priyono, B. (2010). Keanekaragaman Burung di Desa Karangasem Kecamatan Wirosari Kabupaten Grobogan Jawa Tengah. Biosaintifika, 2(2), 82-89.

Rohiyan, M., Setiawan, A., \& Rustiati, E. L. (2014). Keanekaragaman Jenis Burung di Hutan Pinus dan Hutan Campuran Muarasipongi Kabupaten Mandailing Natal Sumatera Utara. Jurnal Sylva Lestari, 2(2), 89-98.

Rusmendro, H. (2009). Perbandingan Keanekaragaman Burung Pada Pagi dan Sore Hari di Empat Tipe Habitat di Wilayah Pangandaran, Jawa Barat. Vis Vitalis, 2(1), 8-16.

Saefullah, A., Mustari, A. H., \& Mardiastuti, A. (2015). Keanekaragaman Jenis Burung pada Berbagai Tipe Habitat Beserta Gangguannya di Hutan Penelitian Dramaga, Bogor, Jawa Barat. Media Konservasi Vol, 20(2), 117-124.

Santosa, R. A., Harianto, S. P., \& Nircahyani, N. (2016). Perbandingan Populasi Burung Cekakak (Halcyonidae) di Lahan Basah Desa Sungai Luar dan Lahan Basah Desa Kibang Pacing Kecamatan Menggala Timur Kabupaten Tulang Bawang. Jurnal Sylva Lestari, 4(2), 79-88.

Sawitri, R., \& Iskandar, S. (2012). Keragaman Jenis Burung di Taman Nasional Kepulauan Wakatobi dan Taman Nasional Kepulauan Seribu. Jurnal Penelitian Hutan dan Konservasi Alam, 9(2), 175-187.

Widodo, W. (2010). Studi Keanekaan Jenis Burung dan Habitatnya di Lereng Timur Hutan Pegunungan Slamet, Purbalingga, Jawa Tengah. Bionatura-Jurnal Ilmu-Ilmu Hayati dan Fisik, 12(2), 68-77.

Winara, A. (2015). Keragaman Jenis Burung Air di Taman Nasional Wasur, Merauke. Jurnal Hutan Tropis, 4(1), 85-92. 